\title{
THE ROLE OF HAND EMBROIDERY IN POVERTY ALLEVIATION: A CASE STUDY OF GADAP TOWN, KARACHI
}

\begin{abstract}
Siraj Bashir ${ }^{*}$
Kinza Farooq**

Abstract

Shakir Adam***

This research work is based upon the social causes of poverty alleviation. Poverty is today's biggest problem in Pakistan. This research made an effort to find out and to discuss the related elements of poverty. The Researcher proposed to study problems and prospects of hand embroidery in the cottage industries, Cottage industry sector plays a dominant role in the economic development of countries. In developing countries cottage industries are especially important in the context of employment opportunities, equitable distribution of national income, balanced regional growth, and development of different areas. A sample of 70 home-based workers selected from convenience sampling in Gadap Town, Karachi. After assembling data, we found that the government is providing the required level of support to hand embroidery, Respondents cannot perform household chores along with their work and create differences in the domestic economic conditions.
\end{abstract}

Keywords: Cottage industry; opportunity; poverty alleviation; hand embroidery; economic conditions

\section{Introduction}

Poverty is a multifaceted economic issue with political and social consequences. It persists across generations and cultures, regardless of cultural allegiance or precise environments. It endures in both rural and urban regions, as well as in developed and emerging economies, despite the fact that its form varies from community to community, culture to culture, and time to time. (Ismail, 2010). ${ }^{1}$

Pakistan is the world's 6th largest country. In terms of population, Pakistan is mainly rural. Pakistan's rural population is totally dependent on agriculture. Rural areas are comparatively poor and about 33 percent of the population lives below the poverty line (Junejo, 2011). ${ }^{2}$ Poverty alleviation has been one of the key goals of development policies in many developed countries. It is a key issue on the agenda of all international

\footnotetext{
This work is Licensed under a Creative Commons Attribution-Non-Commercial 4.0 International License. (c) (1) (8)

* Siraj Bashir, Ph.D. Lecturer, Department of Social Work, University of Balochistan, Quetta

** Kinza Farooq, Research Scholar, Visiting Faculty, Khursheed Government College, Shah Faisal town, Karachi, Social therapist at Karachi Psychiatric Hospital, Karachi.

*** Shakir Adam, Lecturer, Department of Humanities, Lesbela University of Agriculture, Water and Marine Science, Balochistan

${ }^{1}$ Ismail, A. G. (2010). Money, Islamic Banks and Real Economy. Universiti Sains Islam, Malaysia. Retrived From: https://www.researchgate.net/publication/318699636_Money_Islamic_Banks_and_the_Real_Economy

${ }^{2}$ Junejo. (October 7, 2020). Poverty as a social problem of Pakistan. Retrieved From:

http://jamshoro1.wordpress.com/2011/05/16/poverty-as-a-social-problem-of-pakistan/
} 
organizations, including the World Bank $(2000)^{3}$, IFAD $(2001)^{4}$, and ILO $(2003)^{5}$. The World Bank's (2000/2001) study based largely on the problem of poverty also the challenge of ending rural poverty.

Since poverty alleviation is regarded in the literature as a significant economic development issue, attempts have been made to alleviate poverty by raising the level of household income. It has also been the stated aim of every Government policy in Pakistan. However, most attempts have been made to reduce macroeconomic poverty in Pakistan in terms of sustained economic development, job generation by enhancing the functioning of the labor market, the provision of high-quality health and education programs. A significant number of studies have also been carried out on poverty in Pakistan. The present research reflects on the continuation of previous studies, with a focus on a different collection of variables and a micro-level study area. Rural poverty may be eased by reducing family size, individuals per room, and dependence ratios, improving education, increasing female labor force participation, increasing household participation rate, and enhancing assets and access to markets, particularly in distant locations. Apart from certain other socio-economic issues, the government should pay special attention to basic infrastructure and market access amenities. (Chaudhry, 2009) ${ }^{6}$

Urban poverty has emerged as a problem in developing nations, distinguishing itself from rural poverty due to a number of socioeconomic characteristics that have remained unexplored at the national level. (Khan, et al. $(2016)^{7}$ To get rid of poverty and other problems people start small businesses in which the amount of money needed to start any business at home in which the number of people working is called the cottage industry. (Syed, 2019) ${ }^{8}$ In another research conducted by Tasneem \& Biswas (2014), a variety of challenges are faced by cottage industries in Pakistan. It has typically been rural but has expanded to urban areas. From basic indigenous technology-based and homemade goods to sophisticated crafts of a large variety. ${ }^{9}$ The ratio of small businesses and the cottage industry is almost $(80 \%)$ in developing countries (Aslam, 2013) ${ }^{10}$ and the contribution of small and medium-sized enterprises (SMEs) to world activities ranges from (60\%) to

\footnotetext{
${ }^{3}$ World Bank. Poverty in Pakistan: Issues, Priorities and Policy Options: Paper Presented at a Seminar. (Islamabad: World Bank, 2000).

${ }^{4}$ International Fund for Agricultural Development. Rural Poverty Report-2001: The Challenge of Ending Rural Poverty. (Oxford: Oxford University Press, 2001)

${ }^{5}$ International Labor Organization. Working out of poverty. Report of the Director-general in International Labor Conference. (Geneva: ILO, 2003)

${ }^{6}$ Chaudhry, I. M. Poverty Alleviation in Southern Punjab (Pakistan): An Empirical Evidence from the Project Area of Asian Development Bank. International Research Journal of Finance and Economics. Euro Journals Publishing. ISSN 1450-2887 Issue 23, (2009). Retrieved From: http://www.eurojournals.com/finance.htm ${ }^{7}$ Khan, A. U., Saboor, A ., Ali, I. Malik, W. S. \& Mahmood, K. Urbanization of Multidimensional Poverty: Empirical Evidences from Pakistan. Qual Quant 50, (2016), pp.439-469. Retrieved From: https://doi.org/10.1007/s11135-014-0157-x

${ }^{8}$ Syed, H, M. (October 28, 2020). The Cottage Industry, A Neglected Sector In Pakistan. Retrieved From: https://dailytimes.com.pk/427019/the-cottage-industry-a-neglected-sector-in-pakistan/

${ }^{9}$ Tasneem, S., \& Biswas, M. R. Role of Cottage Industry in the Economic Development of Bangladesh: An Empirical Study. IOSR Journal of Business and Management (IOSR-JBM), p-ISSN: 2319-7668. Volume 16, Issue 10.Ver. III, 2014, pp.10-18.

${ }^{10}$ Aslam, A. Moving Towards Micro and Small Enterprise Lending Opportunities and Challenges. (Islamabad: Pakistan Microfinance Network, 2013)
} 
(90\%). (Abe, et al, 2012) ${ }^{11}$. Hence, it would be right to believe that in a country's economic growth, small businesses and cottage industries play a crucial role. (Haider, et al, 2015). ${ }^{12}$

As shown in the World Bank (2013) study, the shortage of credit facilities is nearly (90\%). The nation's people require microfinance, but only (7\%) of needy people have access to the facility. (Aslam, 2013) ${ }^{13}$. Bhattacharyya, (2014) stated that small businesses and large businesses have comparable performance and loss causes. ${ }^{14}$ According to Tunde and Tundui (2012), education cannot be counted as a significant aspect in deciding the success of the cottage industry because students in Tanzania with secondary education (intermediate) are more active and successful entrepreneurs as compare to graduates students. ${ }^{15}$ Small industries play a vital role in development, promoting growth, and spreading industrial awareness across large areas (Ahmed, et al, 1984) ${ }^{16}$. In which hand embroidery is used as both a craft and an art medium. There are many individuals who use it for many purposes and also use it to reduce poverty (Kaur \& Kaur, 2018) ${ }^{17}$.

Ghalib, Malki, and Imai (2011) have indicated that entrepreneurial activities, particularly at the local scale, are critical for any economy's development. They stressed the importance of entrepreneurial activity in emerging countries. Entrepreneurial activities are viewed as a means of achieving self-sufficiency in terms of income and contribution to the country's economy. ${ }^{18}$ Redaelli in (2019) stated that a holistic Islamic approach to poverty reduction would ideally include a set of anti-poverty policies, such as (a) boosting income levels through pro-poor initiatives, (b) establishing an equitable allocation of money, and (c) giving equal opportunities for all socioeconomic groups. ${ }^{19}$

The economic role of women entrepreneurs in reducing poverty in Kenya was analyzed by Misango \& Ongiti in 2013. A case study was performed among woman entrepreneurs within the Central Business District of Nairobi City on the Maasai market. Enterprises

\footnotetext{
${ }^{11}$ Abe, M., Troilo, M., Juneja, J., \&Narain, S. Policy Guidebook for SME Development in Asia and The Pacific. (Bangkok: United Nations Economic and Social commission for Asia and the Pacific Publisher, 2012) ${ }^{12}$ Haider, S H., Asad, M., \& Almansour, A. Z. A. Factors Influencing Growth of Cottage Industry in Punjab, Pakistan: Cottage Industry Owners' Perspective. Paradigms: A Research Journal of Commerce, Economics, And Social Sciences Print ISSN 1996-2800, Online ISSN 2410-0854 2015, Vol. 9, No.1, 2015, pp. 78-87.

${ }^{13}$ Aslam, A. Op.cit.

${ }^{14}$ Bhattacharyya, D. Cottage Industry Clusters in India in Improving Rural Livelihood: An Overview. International Journal of Humanities and Social Science Studies, 1(1), (2014), pp.59-64

${ }^{15}$ Tundui, C., \&Tundui, H. Survival, Growth Strategies and Performance of Women Owned Micro and Small Businesses in Tanzania. International Journal of Business \& Management, 7(8), (2012), pp.143-155.

${ }^{16}$ Ahmed, V., \&Amjad, R. The Management of Pakistan's Economy 1947-82. (New York: Oxford University Press, 1984)

${ }^{17}$ Kaur, R., \& Kaur, J. Traditional Hand Embroidery and Simple Hand-woven Structures for Garment Manufacturing Used in Small Scale Industry. International Journal of Engineering Sciences \& Research Technology, 7(6), 2018, pp.425-432.

${ }^{18}$ Asian Development Bank. "Strategies for Economic Growth and Development." The Bank's Role in Pakistan, (Manila, 1985)

${ }^{19}$ Redaelli, S. Pakistan@100 From Poverty it Equality. Policy Note. World Bank Group, (2019). Retrieved From: https://documents1.worldbank.org/curated/en/868741552632296526/pdf/135319-WP-P163618-14-32019-20-44-35-PakPNFromPovertytoEquityFinal.pdf
} 
have contributed to the promotion of tourism, employment and export trade. Most of the respondents $(83 \%)$ agreed that the firms had helped them boost their economic position. ${ }^{20}$

\section{Literature Review}

The above brief review has demonstrated that small businesses have some challenges that can be regulated, namely the shortage of funding and qualified workers. It is difficult to deny the role of the cottage industry in economic growth. Thus, this study focuses on identifying the exact problems faced by the hand embroidery workers in Gadap Town, Karachi. Cottage businesses are of great significance since they can be taken out with the aid of family members. Wide buildings, large machinery, and great investment are not needed. They're intensive with labor. The biggest advantage in such businesses is that even women and the elderly can use their leisure efficiently in the home.

The main factors of success and failure techniques related to small businesses that lack human resource competence, lack of preparation, lack of finance, and lack of technology, etc. It is important to manage a small business because one is the decision-maker. If the owner gets control, success is assured. (Katz \& Green, n.d.). ${ }^{21}$ Wazir \& Baloch in (2019) stated that the reach of the cottage industry is not limited only to rural areas but has also extended to urban centers. 68.5 percent of SMEs were found to be engaged in needlework work, 24.5 percent in handicrafts, and just $7 \%$ in manufacturing decorative items, according to a study. ${ }^{22}$

In October 1998, Small and Medium Enterprises Development Authority (SMEDA) was founded to take up the challenge of developing small \& medium enterprises. It focuses on providing small and medium businesses with an enabling climate and business growth services. ${ }^{23}$ Strengthening SMEs results in the creation of new employment, which boosts the economy's growth. Small and medium companies account for $90 \%$ of all businesses in Pakistan. (GoP,2017). ${ }^{24}$ Recent reports show that sectors contribute most to a country's economic growth. Analysis has often shown the favorable measures just empower the country's small companies. (Khan, 2018) ${ }^{25}$

As the women not allowed to work outside their households, the cottage industry plays a significant part in the economic development of women employed from home and in rural areas. Approximately (65\%) of women in Pakistan earn their livelihoods from craftwork

\footnotetext{
${ }^{20}$ Misango, S. B., \& Ongiti, O. K. "Do women entrepreneurs play a role in reducing poverty? A case in Kenya," International Review of Management and Business Research, vol. 2, 2013, pp.87-103.

${ }^{21}$ Katz, J. A., \& Green, R. P. (n.d.). Entrepreneurial Small Business. Boston Burr Ridge: McGraw-Hill Irwin.

${ }^{22}$ Wazir, S. \& Baloch, M. A. (2019). Poverty Alleviation Through Home-Based Cottage Industries in Quetta Baalochistan. New Horizons. Vol 13, No 2. Issue No. 26.

${ }^{23}$ Syed, H, M. The Cottage Industry, A Neglected Sector In Pakistan, (2020). Retrieved From:

https://dailytimes.com.pk/427019/the-cottage-industry-a-neglected-sector-in-pakistan/

${ }^{24}$ Government of Pakistan, State of SMEs in Pakistan, 2017. Retrieved From:

http://www.smeda.org/index.php?option=com_content\&view=article \& id=: state-of-smes-

inpakistan\&catid $=15$

${ }^{25}$ Khan, N. Critical Review of Cottage and Small Scale Industries in Pakistan. Industrial Engineer Letters. Vol

8, no 3, 2018, pp. 13-22
} 
and have a significant impact on their household's financial status. (Pin, 2019) ${ }^{26}$ Carpet making, Cutlery, Sport goods, Candle making, Embroidered work, Brassware, Rugs and Traditional bangles making are some special skills of Pakistan, considered important export items and are in good demand in international markets. Two key forms of homebased workers exist. Piece rate workers are those who work for an employer and an agent, while those who work on their own and do their own marketing are the Own Account Workers. There are a variety of such industries in almost every village, depending on the scale of the village and the market for the goods. The development of such an industry is closely linked to the availability of conventional expertise in raw materials, environmental conditions, and in a variety of cases, local specialization in the integrated factory field. In Pakistan, there is a wide range of handicrafts available. It is critical to focus on small and cottage businesses in order to enhance the economy's productivity, since "small scale manufacturing industries in Punjab contribute about 58\% to GDP." Approximately 60\% of the value-added in the country's entire industrial production its industrial sector.(Hasan, $2017)^{27}$

Pakistan's the small-scale industry is the industrial sector's main employer. It is laborintensive, with around (81\%) of the overall labor force hired. There is a lot of opportunity for the development of this industry in Pakistan and we can boost our economy through it. Improvements can be made by making lending on soft terms more readily available. Facilities for promotions can also be strengthened. In comparison to the growth of the new large-scale industries in urban centers, where infrastructure is already disrupted, small-scale and cottage industries should be promoted. The creation of the cottage industry on modern lines is crucial as it is interconnected with our cultural heritage and economic improvement, along with the rise in foreign exchange. (Rizvi, 2011). ${ }^{28}$

Malik, et al, (2000) concluded that in rural areas of Pakistan, land resettlement as a direct policy intervention is perceived to reduce poverty. From the data analysis, a conclusion is drawn that the split inland concentration can help to attain higher agricultural growth rates and, accordingly, to some degree, poverty in rural areas of Punjab may be alleviated. ${ }^{29}$ Fahad and Rehmat (2013) investigated poverty connections using a wide range of macroeconomic variables. They also looked at the impact of structural reform measures on poverty in Pakistan. ${ }^{30}$

Azid, et al, (2001) attempted to clarify the role of female labor force involvement in poverty alleviation through the cottage industry in rural Multan, such as cloth embroidery. They concluded that there is an essential correlation between female employee hours and

\footnotetext{
${ }^{26}$ Pin, G. Role of Women in Cottage Industry. Retrieved From: https://www.pakissan.com/2019/01/22/role-ofwomen-in-cottage-industry/ on October 28, 2020.

${ }^{27}$ Hasan, S. M., Rehman, A., Nabi, I., Hamid, N. \& Naeem, U. Spatial Analysis of Small and Cottage Industries in Punjab, 2017, Reference number: F-37310-PAK-2. Retrieved From: https://www.theigc.org/wpcontent/uploads/2017/09/37310-FINAL.pdf

${ }^{28}$ Rizvi, F. H. Lahore, Encouraging the Cottage Industry. Dawn Newspaper. Retrieved From: https://www.dawn.com/news/599523 on January 11, 2021

${ }^{29}$ Malik, S. Sharif, Imran and Jamal Z. 'Rural Poverty Alleviation Pakistan: Land Redistribution as a Direct Policy Measure,' Journal of Rural Development 33(1): 2000, pp.69-77.

${ }^{30}$ Fahad, I. \& Rehmat, A. Impact of Macroeconomic Policies on Poverty Alleviation in Pakistan," Romanian Economic Business Review, Romanian-American University, vol. 8(4), 2013, pp, 48-60.
} 
household poverty. ${ }^{31}$ Research on urban poverty alleviation by good governance in southern Punjab was also conducted by Chaudhry, et al, (2006). They established that, based on the results of the household survey evidence, good governance of economic infrastructure services, among others, would alleviate poverty in urban areas of southern Punjab. $^{32}$

(Chudhry, 2009) noted that most microfinance schemes fail to serve the poorest families. Most neglected regions have not been covered by health services. He also presented broad recommendations and policy ramifications for enhancing the intended efficacy of poverty reduction narrow-target initiatives in general and zakat in particular. ${ }^{33}$ The nationally implemented poverty reduction programs in Pakistan were studied by (Arif, 2006) in terms of zakat issuance, microfinance and provision of health services using Pakistan Socio-Economic Survey (PSES) data for 2000/01. He argued that public zakat actually protects far fewer households than the real number of qualifying households and that the issue is realistic rather than theoretical. ${ }^{34}$

Researchers began this paper by providing the necessary context facts, after terms that were used by researchers to characterize the role of the hand embroidery in poverty alleviation. Then, to accomplish their aim, they set some targets and some perceptions or ideas to collect research-related facts.

\section{Study Objectives}

- To identify the problems related to this profession.

- To find out the role of hand embroidery.

- To investigate that the families which are engaged in this profession are satisfied or not.

\section{Hypothesis}

- The Government is providing the required level of support to hand embroidery.

- Respondents can also perform household chores along with their work and did this work create any difference in the domestic economic condition.

\footnotetext{
${ }^{31}$ Azid, T., Aslam, M. and Chaudary, M.O. 'Poverty, Female Labor Force Participation, and Cottage Industry: A Case Study of Cloth Embroidery in Rural Multan', The Pakistan Development Review 40 (4): 2001, pp.1105-1118.

${ }^{32}$ Chaudhry, I. S., Malik, S. \& Imran, A. 'Urban Poverty and Governance: The Case of Multan City'. The Pakistan Development Review 45 (4): 2006, pp.819-830.

${ }^{33}$ Chudhry, I. S. Op.cit.

${ }^{34}$ Arif, G. M. Targeting Efficiency of Poverty Reduction Programs in Pakistan, Pakistan Resident Mission

Working Paper. (Islamabad: Asian Development Bank, 2006)
} 


\section{Methodology}

The present research applies a descriptive, cross-sectional which was a quantitative approach, where data were collected from the workers of hand embroidery in the field of the cottage industry in the area of Gadap Town, Karachi. The methodology includes the tool and techniques of the collection and analysis of the data, particularly for testing the hypothesis in an empirical way.

The data were available at internet of 297 hand embroidery workers. So the target population is the full set of individuals who could be included in the study and around which the researcher would like to generalize the finding. The target population consists of 297 women workers who are doing work of hand embroidery in Gadap Town.

In the present study, a sample of 70 home-based workers was the targeted number for the convenience of this study. Convenience sampling (also known as Haphazard Sampling or Accidental Sampling) is a type of nonprobability or nonrandom sampling in which participants are selected for study who meet certain practical criteria, such as easy accessibility, geographical proximity, availability at a specific time, or willingness to participate. (Etikan, et al, 2016) ${ }^{35}$ This technique is considered easiest, cheapest, and least time-consuming.

Data was administered by descriptive survey method through an interview schedule consisting of 65 questions. After completing the tabulation through the SPSS method, the researchers used chi-square to test the hypotheses and final association between the independent and dependent variables, data were cross-tabulated by making contingency tables.

\section{Results}

Results analyzed through the SPSS method. Among 70 hand embroidery workers said that poverty is the main cause of their profession that is $97 \%$ because they work hard and do overtime on their profession but income rate getting low. According to the findings, (79\%) respondents said they started their profession to increase their income because poverty rate increases day by day and it is difficult to fulfill their needs, (86\%) of the participants said their profession is hand embroidery and they are fully dependent on it.

\section{Findings and Discussion}

Individuals living in poverty is a vital topic that reflects on how entrepreneurship can continue to alleviate poverty, while those living in poverty create their own enterprise, on the other hand, entrepreneurship is a mechanism that generates long-lasting solutions for poverty alleviation. (Bruton \& Ketchen, 2013). ${ }^{36}$

\footnotetext{
${ }^{35}$ Etikan, I., Musa, S, A., \& Alkassim, R, S. Comparison of Convenience Sampling and Purposive Sampling. American Journal of Theoretical and Applied Statistics. Vol. 5, No.1, 2016, pp. 1-4. doi: 10.11648/j.ajtas.20160501.11

${ }^{36}$ Bruton, G. D., \& Ketchen, D. J., (2013). "Entrepreneurship as a Solution to Poverty," Journal of Business Venturing, vol. 28, pp.683-689.
} 
Table-1

Respondents by age

\begin{tabular}{|c|c|c|}
\hline Age & Frequency & Percentage \\
\hline Below 15 years & 8 & $11 \%$ \\
\hline 16-20 years & 10 & $14 \%$ \\
\hline 21-25 years & 7 & $10 \%$ \\
\hline 26-30 years & 9 & $13 \%$ \\
\hline Above 30 years & 36 & $51 \%$ \\
\hline Total & 70 & $100 \%$ \\
\hline
\end{tabular}

Table- 1 shows the respondents ages that around $51 \%$ of participants are over 30 years of age, $14 \%$ of respondents falls within the age group of 16 to 20 years, $13 \%$ of respondents fall within the group of 26-30 years of age. The Table showed that most women are married, to support their husbands; to overcome the economic hurdles they do the job like home-based workers (HBWs) as shown in Table-2.

Table-2

Respondents by marital status

\begin{tabular}{|c|c|c|}
\hline Marital status & Frequency & Percentage \\
\hline Married & 34 & $49 \%$ \\
\hline Unmarried & 29 & $41 \%$ \\
\hline Divorced & 1 & $1 \%$ \\
\hline Widow & 6 & $9 \%$ \\
\hline Total & 70 & $100 \%$ \\
\hline
\end{tabular}

The table indicates the marital status of the respondents that $49 \%$ are married. $41 \%$ of respondents are unmarried. Whereas only $9 \%$ of respondents are widows. Sudarshan and Sinha's (2001) research on the significance of domestic markets for home-based work in South Asia. Women HBWs face multiple disadvantages due to poverty, poor habitat, and the unsuitability of their houses for working and storing goods. ${ }^{37}$

Table-3

Respondents by their earning per piece

\begin{tabular}{|c|c|c|}
\hline Earning per piece & Frequency & Percentage \\
\hline Rs.2.99 to 4.99 & 12 & $17 \%$ \\
\hline Rs.4.99 to 6.99 & 43 & $61 \%$ \\
\hline Rs.6.99 to 8.99 & 6 & $9 \%$ \\
\hline Rs.8.99 to 10.99 & 1 & $1 \%$ \\
\hline Above rs. 10.99 & 8 & $11 \%$ \\
\hline Total & 70 & $100 \%$ \\
\hline
\end{tabular}

${ }^{37}$ Sudarshan, R. M., \& Sinha, S. Women in Informal Employment: Globalizing and Organizing (WIEGO). Making Home-Based Work Visible. Manchester.M2 7EN, (United Kingdom, 2001) 
It clearly shows that the highest numbers of respondents are earning per piece 4.99 to 6.99 per piece $61 \%$ of data. $17 \%$ of participants are earning per piece 2.99 to 4.99 . Whereas $11 \%$ of respondents are earning per piece above 10.99 rupees. That definitely shows that the economy's scale is very low that increases the poverty rate among hand embroidery workers.

Table-4

What respondent's daily wage is?

\begin{tabular}{|c|c|c|}
\hline Daily wage & Frequency & Percentage \\
\hline Below Rs.100 till 199.5 & 64 & $91 \%$ \\
\hline Rs .199.5 to Rs.499.5 & 5 & $7 \%$ \\
\hline Rs .499.5 to Rs. 799.5 & 1 & $1 \%$ \\
\hline Total & 70 & $100 \%$ \\
\hline
\end{tabular}

The result reveals that HBW s daily earnings are so less and their job is so challenging and critical. The table indicates that respondent's daily wage below Rs. 100 to 199.5 which is $91 \%$. The second-highest number shows that respondent's daily wage Rs. 199.5 to 499.5 which formed 7\%. The third highest number shows that respondent's daily wage Rs.499.5 to 799.5 which formed $1 \%$ of the data. Modernization and high rates of economic growth are not displacing it. Home-based work for domestic demand is so profoundly rooted in output that it has now become part of global supply chains. (Gereffi, et al, 2005). ${ }^{38}$

Table-5

Respondent's problems are being faced by their profession

\begin{tabular}{|c|c|c|}
\hline Problems faced & Frequency & Percentage \\
\hline Lack of marketing & 40 & $27 \%$ \\
\hline Lack of advertisement & 46 & $31 \%$ \\
\hline Lack of finance & 22 & $15 \%$ \\
\hline Lack of import policy & 12 & $8 \%$ \\
\hline All of them & 30 & $20 \%$ \\
\hline Total & 150 & $100 \%$ \\
\hline
\end{tabular}

Table-5 indicates that the highest number of respondents said lack of advertisement is the main problem faced by their profession that is $31 \%$. Whereas the second-highest number of respondents is lack of marketing that represents $27 \%$. While $20 \%$ of respondents mentioned all kinds of problems are being faced that is $20 \%$. (Lee, 2014) highlight the major issues of cottage industry are profits are minimal and they are often spent on the owners' daily expenses. They do not have extra money for these manufacturing units to develop. There are no economies of scale available, so manufacturing prices are higher in small-scale factories. The wholesaler, who takes much of the money, is manipulating the

\footnotetext{
${ }^{38}$ Gereffi, G., Humphrey, J., \& Sturgeon, T. "The Governance of Global Value Chains," Review of International Political Economy, 12(1), 2005, pp. 78-104.
} 
industry's buyers. This discourages the owners and reduces the quality and quantity produced. ${ }^{39}$

Table-6

Factors which are affecting the family life of respondents

\begin{tabular}{|c|c|c|}
\hline Factors affecting the family life & Frequency & Percentage \\
\hline Poverty & 60 & $38 \%$ \\
\hline Load shedding & 51 & $32 \%$ \\
\hline Less time & 20 & $13 \%$ \\
\hline Illiteracy & 28 & $18 \%$ \\
\hline Total & 159 & $100 \%$ \\
\hline
\end{tabular}

The table illustrates the highest number of respondents that $38 \%$ said poverty is the factor. The second-highest number of respondents that $32 \%$ said load shedding is the factor. While the rest of the respondents that $18 \%$ said Illiteracy is the factor. In 2006, Singer assumed that the best solution for alleviating poverty in every area of the world lies in fostering more business enterprises and launching new projects through the growth of entrepreneurship. In addition, through new knowledge development and implementation, entrepreneurship creates a foundation for economic progress. ${ }^{40}$

A UNIFEM analysis found a significant number of household women assembling bicycle parts in Ludhiana; since 70\% of the women sampled had husbands who were technicians in neighboring factories or who were self-employed in technical trades, it seems that "the presence of household women in the bicycle manufacturing trade can be considered as a spillover of the technical occupations performed by bicycle manufacturers". (UNIFEM 2000: 80). ${ }^{41}$

\footnotetext{
${ }^{39}$ Lee. L. What Types of Products are Made in Cottage Industry? Retrieved From: http://www.wisegeek.com/what-types-of-products-are-made-in-a-cottage-industry.htm on January 22, 2021 ${ }^{40}$ Singer, A. E. "Business Strategy and Poverty Alleviation," Journal of Business Ethics, vol. 66, 2006, pp. 225-231.

${ }^{41}$ UNIFEM. A Preliminary Study on the Productive Linkages of Indian Industry with Home-based Women Workers through Subcontracting Systems in Manufacturing Sector. (New Delhi: United Nations Development Fund for Women, 2000)
} 
Table-7

Requesting answers to respondents as follows:

\begin{tabular}{|c|l|c|c|c|}
\hline S.No. & \multicolumn{1}{|c|}{ Answers to respondents } & $\begin{array}{c}\text { Yes } \\
\text { (percentage) }\end{array}$ & $\begin{array}{c}\text { No } \\
\text { (percentage) }\end{array}$ & Percentage \\
\hline 01. & $\begin{array}{l}\text { Respondents is this profession } \\
\text { hand embroidery }\end{array}$ & 86.00 & 14.00 & 100.00 \\
\hline 02. & $\begin{array}{l}\text { Respondent's profession is } \\
\text { their inherited }\end{array}$ & 9.00 & 91.00 & 100.00 \\
\hline 03. & $\begin{array}{l}\text { Respondents started their } \\
\text { profession to increase their } \\
\text { income }\end{array}$ & 79.00 & 21.00 & 100.00 \\
\hline 04. & $\begin{array}{l}\text { Respondent's Satisfied with } \\
\text { their wage }\end{array}$ & 59.00 & 41.00 & 100.00 \\
\hline 05. & $\begin{array}{l}\text { Respondent's know where } \\
\text { their products sent }\end{array}$ & 91.00 & 9.00 & 100.00 \\
\hline 06. & $\begin{array}{l}\text { Government providing support } \\
\text { to this profession }\end{array}$ & 89.00 & 11.00 & 100.00 \\
\hline 07. & $\begin{array}{l}\text { Respondents think they are } \\
\text { doing this job because are } \\
\text { uneducated }\end{array}$ & 46.00 & 54.00 & 100.00 \\
\hline 08. & $\begin{array}{l}\text { Poverty is the biggest reason } \\
\text { of their problems }\end{array}$ & 97.00 & 3.00 & 100.00 \\
\hline
\end{tabular}

The purpose of the present study is to discover the level of knowledge, highlight the problems and hurdles faced by hand embroidery workers and the main causes of poverty alleviation in Gadap Town, Karachi. Table: 7 shown that $(86 \%)$ of the data said their profession is hand embroidery and (14\%) of respondents said they are not completely dependent on this profession while $(91 \%)$ respondents said their profession isn't inherited while (9\%) said it is inherited profession. Gereffi, Humphrey, and Sturgeon's (2005) analysis identified five global value chain governance types. Outsourcing and home-based work are compatible with more than one type of network governance. They claim that the complexity of knowledge, the capacity to codify it, and the capacities of current and prospective suppliers influence the particular market type that arises in each given sector or region. It has been noted at the same time that: "Wide-scale outsourcing may be antithetical to long-standing corporate policies and organizations, such as lifetime jobs in large corporations, which make it incredibly difficult and sluggish to reorganize the radical industry" (Gereffi, et al, 2005). ${ }^{42}$

In the present research, $(79 \%)$ respondents said they started their profession to increase their income. Because of the increase of inflation day by day and resources are limited, school fees, tuition fees, and other expenditures consume all income that's why women work to support their husbands. On the other end, concentrated, small-scale home-based

${ }^{42}$ Gereffi, G., Humphrey, J., \& Sturgeon, T. "The Governance of Global Value Chains," Review of International Political Economy, 12(1), 2005, pp.78-104. 
development, the South Asian region seems to be mostly immune to attempts to get jobs and staff into a factory or work shed. Poverty was a source of shame, social estrangement, and psychological instability for Smith, according to Terry Peach (2010) . Wage workers, Smith felt, would not face genuine suffering. Smith observes that economic imbalance existed in all civilizations from the time of hunting to the time of herding. ${ }^{43}$

In HBW's opinion (59\%) said they were happy with salaries and (91\%) respondents said they knew their goods sent as seen in Table: 7

A research conducted by Rank (2004) suggests that poverty is a life-course event that affects most Americans. 58.5\% of the population will suffer poverty at least once. Economic hypotheses aim to illustrate the nature and prevalence of suffering to guide social welfare practice. ${ }^{44}$ Table: 7 shown that $(89 \%)$ respondents said Government providing support to this profession whereas $(46 \%)$ respondents think they are doing this job because they are educated most are intermediated and graduated and (97\%) respondents said poverty is the biggest reason for their problems, every problem starts with it.

In table- 8 variables denotes as $\mathrm{m} 1$ and $\mathrm{m} 2$ which used in hypothesis "The Government is providing the required level of support to home-based work/hand embroidery (zari work)."

In table- 9 variables denotes as $m 1$ and $m 2$ which used in the hypothesis "Respondents can perform house hold chores along with their work and create any difference in the domestic economic conditions."

Table-8

Hypothesis 1 testing with SPSS

$\mathrm{m} 1=$ considered as Government providing support to this profession $\mathrm{m} 2=$ considered as hand embroidery existent in area of Gadap Town

\begin{tabular}{|c|c|c|c|c|c|c|}
\hline \multicolumn{7}{|c|}{ Case Processing Summary } \\
\hline & \multicolumn{7}{c|}{ Cases } \\
\hline & \multicolumn{2}{|c|}{ Valid } & \multicolumn{2}{c|}{ Missing } & \multicolumn{2}{c|}{ Total } \\
\hline & $\mathrm{N}$ & Percent & $\mathrm{N}$ & Percent & $\mathrm{N}$ & Percent \\
\hline $\mathrm{m} 1 * \mathrm{~m} 2$ & 140 & $100.0 \%$ & 0 & $0.0 \%$ & 140 & $100.0 \%$ \\
\hline
\end{tabular}

${ }^{43}$ Peach, T. History of Political Economy. 2010, Retrived From: read.dukeupress.edu

${ }^{44}$ Jung, S. Y., \& Smith, R. J. The Economics of Poverty: Explanatory Theories Of Inform Practice. Journal of Human Behavior in the Social Environment. 16: 1-2, 2007, pp.21-39, DOI: 10.1300/J137V16n0103. 


\begin{tabular}{|c|c|l|c|c|c|}
\hline \multicolumn{5}{|c|}{ m1 * m2 Cross-tabulation } \\
\hline \multirow{2}{*}{$\mathrm{m} 1$} & \multirow{2}{*}{ Yes } & & \multicolumn{2}{c|}{$\mathrm{m} 2$} & \multirow{2}{*}{ Total } \\
\hline & & & Yes & No & 70 \\
\cline { 3 - 6 } & & Expected Count & 61.0 & 9.0 & 70.0 \\
\cline { 3 - 6 } & \multirow{2}{*}{ No } & Count & 62 & 8 & 70 \\
\cline { 3 - 6 } & & Expected Count & 61.0 & 9.0 & 70.0 \\
\hline \multirow{2}{*}{ Total } & Count & 122 & 18 & 140 \\
\cline { 3 - 6 } & & Expected Count & 122.0 & 18.0 & 140.0 \\
\hline
\end{tabular}

\begin{tabular}{|l|c|c|c|c|c|}
\hline \multicolumn{7}{|c|}{ Chi-Square Tests } \\
\hline & Value & df & $\begin{array}{c}\text { Asymp. Sig. } \\
\text { (2-sided) }\end{array}$ & $\begin{array}{c}\text { Exact Sig. } \\
\text { (2-sided) }\end{array}$ & $\begin{array}{c}\text { Exact Sig. } \\
\text { (1-sided) }\end{array}$ \\
\hline Pearson Chi-Square & $0.255 \mathrm{a}$ & 1 & 0.614 & & \\
\hline Continuity Correctionb & 0.064 & 1 & 0.801 & & \\
\hline Likelihood Ratio & 0.255 & 1 & 0.613 & & 0.401 \\
\hline Fisher's Exact Test & & & & 0.801 & \\
\hline $\begin{array}{l}\text { Linear-by-Linear } \\
\text { Association }\end{array}$ & 0.253 & 1 & 0.615 & & \\
\hline N of Valid Casesb & 140 & & & & \\
\hline a. 0 cells (.0\%) have expected count less than 5. The minimum expected count is 9.00. \\
\hline \\
b. Computed only for a 2x2 table & & & & \\
\hline
\end{tabular}

\begin{tabular}{|c|c|c|c|}
\hline \multicolumn{4}{|c|}{ Symmetric Measures } \\
\hline & & Value & Approx. Sig. \\
\hline Nominal by Nominal & Contingency Coefficient & 0.043 & 0.614 \\
\hline \multicolumn{2}{|c|}{ N of Valid Cases } & 140 & \\
\hline
\end{tabular}


In Table-8, through SPSS researchers applied cross tabulation between $\mathrm{m} 1$ (the government providing support to this profession, Yes 60, No 10) and $\mathrm{m} 2$ (hand embroidery existent in area of Gadap Town, Yes 62, No 8) and then apply chi-square test. The results found that there is no association between $\mathrm{m} 1$ and $\mathrm{m} 2$. The hypothesis was rejected.

\section{Table-9}

\section{Hypothesis 2 testing with SPSS}

$\mathrm{m} 1=$ respondents can perform house hold chores along with their work. $\mathrm{m} 2=$ creates any difference in the domestic economic conditions.

\begin{tabular}{|c|c|c|c|c|c|c|}
\hline \multicolumn{7}{|c|}{ Case Processing Summary } \\
\hline & \multicolumn{7}{|c|}{ Cases } \\
\hline & \multicolumn{2}{|c|}{ Valid } & \multicolumn{2}{c|}{ Missing } & \multicolumn{2}{c|}{ Total } \\
\hline & $\mathrm{N}$ & Percent & $\mathrm{N}$ & Percent & $\mathrm{N}$ & Percent \\
\hline $\mathrm{m} 1 * \mathrm{~m} 2$ & 140 & $100.0 \%$ & 0 & $.0 \%$ & 140 & $100.0 \%$ \\
\hline
\end{tabular}

\begin{tabular}{|c|c|c|c|c|c|}
\hline \multicolumn{6}{|c|}{$\mathrm{m} 1 * \mathrm{~m} 2$ Crosstabulation } \\
\hline & & & \multicolumn{2}{|c|}{$\mathrm{m} 2$} & \multirow[b]{2}{*}{ Total } \\
\hline & & & Yes & No & \\
\hline \multirow[t]{4}{*}{$\mathrm{m} 1$} & \multirow[t]{2}{*}{ Yes } & Count & 53 & 17 & 70 \\
\hline & & Expected Count & 56.0 & 14.0 & 70.0 \\
\hline & \multirow[t]{2}{*}{ No } & Count & 59 & 11 & 70 \\
\hline & & Expected Count & 56.0 & 14.0 & 70.0 \\
\hline \multirow{2}{*}{\multicolumn{2}{|c|}{ Total }} & Count & 112 & 28 & 140 \\
\hline & & Expected Count & 112.0 & 28.0 & 140.0 \\
\hline
\end{tabular}




\section{Chi-Square Tests}

\begin{tabular}{|c|c|c|c|c|c|}
\hline & Value & $\mathrm{df}$ & $\begin{array}{l}\text { Asymp. Sig. } \\
\text { (2-sided) }\end{array}$ & $\begin{array}{l}\text { Exact Sig. } \\
\text { (2-sided) }\end{array}$ & $\begin{array}{l}\text { Exact Sig. } \\
\text { (1-sided) }\end{array}$ \\
\hline Pearson Chi-Square & $1.607 \mathrm{a}$ & 1 & 0.205 & & \\
\hline Continuity Correctionb & 1.116 & 1 & 0.291 & & \\
\hline Likelihood Ratio & 1.617 & 1 & 0.203 & & \\
\hline Fisher's Exact Test & & & & 0.291 & 0.145 \\
\hline $\begin{array}{l}\text { Linear-by-Linear } \\
\text { Association }\end{array}$ & 1.596 & 1 & 0.207 & & \\
\hline $\mathrm{N}$ of Valid Casesb & 140 & & & & \\
\hline
\end{tabular}

a. 0 cells $(.0 \%)$ have expected count less than 5 . The minimum expected count is 14.00 .

b. Computed only for a $2 \times 2$ table

\begin{tabular}{|c|c|c|c|}
\hline \multicolumn{4}{|c|}{ Symmetric Measures } \\
\hline & & Value & Approx. Sig. \\
\hline Nominal by Nominal & Contingency Coefficient & 0.107 & 0.205 \\
\hline \multicolumn{2}{|c|}{ N of Valid Cases } & 140 & \\
\hline
\end{tabular}

In Table-9, through SPSS researchers applied cross tabulation between $\mathrm{m} 1$ (respondents can perform house hold chores along with their work, Yes 53, No 17), m2 (creates any difference in the domestic economic conditions, Yes 59, No 11) and then apply chi-square test. The results found that there is no association between $\mathrm{m} 1$ and $\mathrm{m} 2$. The hypothesis was rejected.

\section{Conclusion}

The study concluded that hand embroidery women didn't work hard with their home chores. The majority of $49 \%$ of married women are engaged in hand embroidery to increase their economic resources but their job is so challenging and critical and it affects their health too. The government is not providing support and encouragement to these hand embroidery workers that is a big loss of our country's talent. We conducted two hypotheses both were rejected and there were no association between them. 


\section{Recommendations}

- Increase access to affordable finance and financial support services to improve their financial condition.

- Respondents should be provided short and long terms debts low on interest rates.

- There should be proper strategic planning and a complete framework for respondents.

- Government should establish unions to support the cottage industry. As we have not found a single union working for the cottage industry.

- During research we have found many child laborers in different surveys that are unlawful according to Pakistan's law.

- Government should contingency plans to abstain child labor work and to provide free education to them.

- There should be proper export planning by the government that would also improve the revenue.

- During the research, we have found if this industry is taken care of highly so the domestic economic condition will be better and will be able to provide job opportunities.

- We have also found during research that health care facilities should be provided free of cost to the labor/member of the cottage industry.

- The scarcity of housing and threats to environmental health in urban areas could be reduced by promoting urban land reform and extending water and sanitation services.

- There should be proper marketing and advertising of hand embroidery and other cottages products.

\section{Bibliography}

Ismail, A. G. (2010). Money, Islamic Banks and Real Economy. Universiti Sains Islam, Malaysia. Retrived From: https://www.researchgate.net/publication/318699636_Money_Islamic_Banks_and_t he_Real_Economy 
Junejo. (October 7, 2020). Poverty as a social problem of Pakistan. Retrieved From: http://jamshoro1.wordpress.com/2011/05/16/poverty-as-a-social-problem-ofpakistan/

World Bank. (2000). Poverty in Pakistan: Issues, Priorities and Policy Options: Paper Presented at a Seminar. Islamabad: World Bank.

International Fund for Agricultural Development. (2001). Rural Poverty Report2001: The Challenge of Ending Rural Poverty. Oxford: Oxford University Press.

International Labor Organization. (2003). Working out of poverty. Report of the Director-general in International Labor Conference. Geneva: ILO.

Chaudhry, I. M. (2009). Poverty Alleviation in Southern Punjab (Pakistan): An Empirical Evidence from the Project Area of Asian Development Bank. International Research Journal of Finance and Economics. EuroJournals Publishing. ISSN 1450-2887 Issue 23. Retrieved From:

http://www.eurojournals.com/finance.htm

Khan, A. U., Saboor, A ., Ali, I. Malik, W. S. \& Mahmood, K. (2016). Urbanization of Multidimensional Poverty: Empirical Evidences from Pakistan. Qual Quant 50, pp.439-469. Retrieved From: https://doi.org/10.1007/s11135-014-0157-x

Syed, H, M. (October 28, 2020). The Cottage Industry, A Neglected Sector In Pakistan. Retrieved From: https://dailytimes.com.pk/427019/the-cottage-industry-aneglected-sector-in-pakistan/

Tasneem, S., \& Biswas, M. R. (2014). Role of Cottage Industry in the Economic Development of Bangladesh: An Empirical Study. IOSR Journal of Business and Management (IOSR-JBM), p-ISSN: 2319-7668. Volume 16, Issue 10.Ver. III, pp.10-18.

Aslam, A. (2013). Moving Towards Micro and Small Enterprise Lending Opportunities and Challenges. Islamabad: Pakistan Microfinance Network.

Abe, M., Troilo, M., Juneja, J., \&Narain, S. (2012). Policy Guidebook for SME Development in Asia and the Pacific. Bangkok: United Nations Economic and Social commission for Asia and the Pacific Publiher.

Haider, S H., Asad, M., \&Almansour, A. Z. A. (2015). Factors Influencing Growth of Cottage Industry in Punjab, Pakistan: Cottage Industry Owners' Perspective. Paradigms: A Research Journal of Commerce, Economics, And Social Sciences Print ISSN 1996-2800, Online ISSN 2410-0854 2015, Vol. 9, No. 1, pp. 78-87.

Aslam, A. (2013). Moving Towards Micro and Small Enterprise Lending Opportunities and Challenges. Islamabad: Pakistan Microfinance Network. 
Bhattacharyya, D. (2014). Cottage Industry Clusters in India in Improving Rural Livelihood: An Overview. International Journal of Humanities and Social Science Studies, 1(1), pp.59-64

Tundui, C., \&Tundui, H. (2012). Survival, Growth Strategies and Performance of Women Owned Micro and Small Businesses in Tanzania. International Journal of Business \& Management, 7(8), pp.143-155.

Ahmed, V., \&Amjad, R. (1984). The Management of Pakistan's Economy 1947-82. New York: Oxford University Press.

Kaur, R., \& Kaur, J. (2018). Traditional Hand Embroidery and Simple Hand-woven Structures for Garment Manufacturing Used in Small Scale Industry. International Journal of Engineering Sciences \& Research Technology, 7(6), pp.425-432.

Asian Development Bank. (1985). "Strategies for Economic Growth and Development." The Bank's Role in Pakistan. Manila.

Redaelli, S. (2019). Pakistan@ 100 From Poverty ti Equality. Policy Note. World Bank Group. Retrieved From:

https://documents1.worldbank.org/curated/en/868741552632296526/pdf/135319WP-P163618-14-3-2019-20-44-35-PakPNFromPovertytoEquityFinal.pdf

Misango, S. B., \&Ongiti, O. K. (2013). "Do women entrepreneurs play a role in reducing poverty? A case in Kenya," International Review of Management and Business Research, vol. 2, pp.87-103.

Katz, J. A., \& Green, R. P. (n.d.). Entrepreneurial Small Business. Boston Burr Ridge: McGraw-Hill Lrwin.

Wazir, S. \& Baloch, M. A. (2019). Poverty Allivaition Through Home-Based Cottage Industries in Quetta Baalochistan. New Horizons. Vol 13, No 2. Issue No. 26.

Syed, H, M. (October 28,2020). The Cottage Industry, A Neglected Sector In Pakistan. Retrieved From: https://dailytimes.com.pk/427019/the-cottage-industry-aneglected-sector-in-pakistan/

Government of Pakistan. (2017). State of SMEs in Pakistan. Retrieved From: http://www.smeda.org/index.php?option=com_content\&view=article \& id=: stateof-smes-inpakistan \&catid $=15$

Khan, N. (2018). Critical Review of Cottage and Small Scale Industries in Pakistan. Industrial Engineer Letters. Vol 8, no 3. pp 13-22.

Pin, G. (October 28, 2020). Role of Women in Cottage Industry. Retrieved From: https://www.pakissan.com/2019/01/22/role-of-women-in-cottage-industry/ 
Hasan, S. M., Rehman, A., Nabi, I., Hamid, N. \& Naeem, U. (2017). Spatial Analysis of Small and Cottage Industries in Punjab. Reference number: F-37310PAK-2. Retrived From: https://www.theigc.org/wpcontent/uploads/2017/09/37310-FINAL.pdf

Rizvi, F. H. (January 11, 2021), Lahore, Encouraging the Cottage Industry. Dawn Newspaper. Retrieved From: https://www.dawn.com/news/599523

Malik, S. Sharif, Imran and Jamal Z. (2000). 'Rural Poverty Alleviation Pakistan: Land Redistribution as a Direct Policy Measure,' Journal of Rural Development 33(1): pp.69-77.

Fahad, I. \& Rehmat, A. (2013). Impact Of Macroeconomic Policies On Poverty Alleviation In Pakistan," Romanian Economic Business Review, RomanianAmerican University, vol. 8(4), pp, 48-60.

Azid, T., Aslam, M. and Chaudary, M.O. (2001). 'Poverty, Female Labor Force Participation, and Cottage Industry: A Case Study of Cloth Embroidery in Rural Multan', The Pakistan Development Review 40 (4): pp.1105-1118.

Chaudhry, I. S., Malik, S. \& Imran, A. (2006). 'Urban Poverty and Governance: The Case of Multan City'. The Pakistan Development Review 45 (4): pp.819-830.

Chudhry, I. S. (2009). Poverty Alleviation in Southern Punjab (Pakistan): An Empirical Evidence from the Project Area of Asian Development Bank .International Research Journal of Finance and Economics, ISSN 1450-2887 Issue 23.

Arif, G. M. (2006). Targeting Efficiency of Poverty Reduction Programs in Pakistan, Pakistan Resident Mission Working Paper. Islamabad: Asian Development Bank.

Paulette, R. (2008). "Triangulation." In Given, Lisa (Ed.), "The SAGE Encyclopedia of Qualitative Research Methods." Sage Publications. Pp. 892-894.

Hayes, A. (February 27, 2021). Stratified Random Sampling Retrieved From: http://www.investopedia.com/terms/stratified_random_sampling.asp.

Etikan, I., Musa, S, A., \& Alkassim, R, S. (2016). Comparison of Convenience Sampling and Purposive Sampling. American Journal of Theoretical and Applied Statistics. Vol. 5, No. 1, pp. 1-4. doi: 10.11648/j.ajtas.20160501.11

Bruton, G. D., \& Ketchen, D. J., (2013). "Entrepreneurship as a solution to poverty," Journal of Business Venturing, vol. 28, pp.683-689.

Sudarshan, R. M., \& Sinha, S. (2001). Women in Informal Employment: Globalizing and Organizing (WIEGO). Making Home-Based Work Visible. Manchester.M2 7EN, United Kingdom. 
Gereffi, G., Humphrey, J., \& Sturgeon, T. (2005). “The Governance of Global Value Chains," Review of International Political Economy, 12(1), pp. 78-104.

Lee. L. (January 22, 2021). What Types of Products are made in Cottage Industry? Retrieved From: http://www.wisegeek.com/what-types-of-products-are-made-in-acottage-industry.htm

Singer, A. E. (2006). "Business strategy and poverty alleviation," Journal of Business Ethics, vol. 66, pp.225-231.

UNIFEM. (2000). A Preliminary Study on the Productive Linkages of Indian Industry with Home-based Women Workers through Subcontracting Systems in Manufacturing Sector. New Delhi: United Nations Development Fund for Women.

Gereffi, G., Humphrey, J., \& Sturgeon, T. (2005). "The Governance of Global Value Chains," Review of International Political Economy, 12(1), pp.78-104.

Peach, T. (2010). History of Political Economy. Retrived From: read.dukeupress.edu

Jung, S. Y., \& Smith, R. J. (2007). The Economics of Poverty: Explanatory Theories Of Inform Practice. Journal of Human Behavior in the Social Environment. 16: 1-2, pp.21-39, DOI: 10.1300/J137V16n0103. 